\title{
Gender Diversity of Boards, Board Composition and Firm Performance
}

\author{
Nebert Mandala (MBA, CPAK, CPSK, CISA), PhD Candidate \\ Prof. Erasmus Kaijage \\ Prof. Josiah Aduda \\ Dr. Cyrus Iraya (PhD), Senior Lecturer
}

School of Business, University of Nairobi, Kenya

Doi: 10.19044/esj.2017.v13n34p62 URL:http://dx.doi.org/10.19044/esj.2017.v13n34p62

\begin{abstract}
The broad objective of this research was to determine whether gender diversity of boards and board composition, affects performance. Secondary data was collected for a ten-year period from 2006 to 2015 from 98 sampled financial institutions. Multiple regression analysis and generalized estimating equations were used in analysis of the collected data. Parametric and nonparametric methodologies were used. The study was anchored on the agency theory, stakeholder theory, the human capital theory and resource dependence theory. The results show that, gender diversity of boards and board composition had no independent significant influence on performance of financial institutions. Through the study formulation of managerial policy and practice that promote better governance practices and appropriate firm characteristics that improve performance of financial institutions will be enhanced.
\end{abstract}

Keywords: Gender diversity, Board Composition and Firm Performance

\section{Introduction}

Boards of directors provide an internal governance mechanism (versus the external governance from shareholders and other external stakeholders) that is particularly important in order to oversee and advise the organization's managers (Hillman \& Dalziel, 2003). For board members to efficiently oversee and advise, they need to have a structure that supports such activities (Jackling \& Johl, 2009; Pearce \& Zahra, 1992). Workforce gender diversity has attracted the attention of press and scholars over time. In particular, focus has been laid on addressing "glass ceiling effect" (Farrell \& Hersch, 2001, p.30). Many scholars have researched on the trend and effect of workforce diversity on firm performance and especially among the high 
level managers. (Terjesen, \& Singh, 2008; Dejardin, 2009). When top management is comprised of female employees, it is anticipated that it will positively affect firm performance. On the contrary, it has been argued that gender diversity can negatively affect firm performance by increasing absenteeism and turnover. It may also end up creating conflict which breaks the team spirit. (Herring, 2009).

Empirical evidence has yielded mixed and contradictory results on the optimal board structure (Dalton et al., 1998). However, most are in agreement about the important variables representing board structure and that may have an impact on the monitoring and thus performance. The debate about influence of gender diversity on firm performance however, continues since results of previous studies have been conflicting (Dalton et al., 1998). This suggests that there are other intervening factors like board Composition and firm characteristics which come into play. In transition economies, ownership concentration is high and relates to corporate governance, financing and investment in the organization. Most firms are saturated with institutional investors with a small stake left for retail investors. Ownership for most firms is distributed among institutional investors and retail investors; with ownership concentrated mainly to institutional investors (Shleifer \& Vishny, 1997).

Conceptualization in this study is underpinned by the agency theory whose key paradigm is the agency conflict. This conflict occurs when the principal assigns another the agent services that should be done in a particular manner (Ross 1973). Other theories include the resource dependence theory (Pfeffer \& Salancik, 1978). The theory attributes production of a firm's assets to the board members. These assets shape the behavior of the organization and its environment. Stakeholder theory forms a theoretical foundation for board diversity. It is worth noting that corporate governance theories focus on the owner's interests and ignore other stakeholders. Stakeholder theory therefore brings attention to the managers' duty of protecting long-term interests of all stakeholders and this influences the board's role. (Freeman \& Evan, 1988). Johnson and Greening (1999) argued that when stakeholder groups are represented by board members, they give insight into the expectations of the various stakeholders. Human capital theory is the fourth and is important in explaining the association among board diversity and firm performance.

According to Becker (1964), human capital theory addresses the role of an individual's education, experience, and skills that will be of use to the firm (Terjesen, Sealy, and Singh, 2009 in Carter 2010). 


\section{Research Objectives}

The general objective of this research was to determine whether a relationship exists among gender diversity of boards, board composition and performance of financial institutions in Kenya.

\section{Empirical Review}

\section{Gender Diversity of Boards}

Corporate diversity has been defined variously. One approach looks at as differences in the age, ethnicity, race, gender, and social/cultural identities among employees in the institution (Marimuthu, 2008). Van der Walt and Ingley (2003) defined board diversity as the blend of attributes, traits and skills possessed by the board members. This also applies to top management in a firm. Gender diversity can also be defined as consideration of women and men as equal resources. Gender diversity in the working environment refers to the mix of men and women in the workplace (Herring 2009). Boardroom gender diversity is the presence of women in the board (Dutta \& Bose 2006). This study adopts the definition by Dutta and Bose (2006).

Empirical evidence on the association among gender diversity and organizational effectiveness cannot be easily interpreted. At first glance there exists a positive correlation among diversity and institutional performance. However, with introduction of other board structure variables, this correlation fades away. The reverse causality on the other hand is detrimental to the relationship. Some studies have argued that firm's strategies can affect the ability of female directors to affect institutional performance (Dezsò \& Ross, 2012) and willingness to take the risk (Smith, Smith \& Verner, 2006). Generally, business case evidence for female directors is found to cut both sides.

Some prior studies have shown that board diversity positively affects firm financial performance (Carter et al., 2003; Erhardt et al., 2003; Kiel \& Nicholson, 2003) while some concluded otherwise (Adams \& Ferreira, 2009; Carter et al., 2010; De Andres et al., 2005; Rose, 2007). Despite mixed results regarding the impact of board diversity on performance, board composition diversity is favored for these key reasons (Kang, Cheng, \& Gray, 2007). First is that diversity boosts discussion and sharing of ideas which enhances performance. Board diversity provides different ideas and views in facing problems and solving them. This way, better decisions are made and firm performance is enhanced. Secondly, the board's role of protecting stakeholders' interests can better be achieved when all the stakeholders are represented in the board. Board diversity can be seen as an ideal way of being 'representative'. Kamaara, Gachunga and Waititu (2013) concluded that there is a strong association among board characteristics and 
performance of state corporations in Kenya. Letting, Aosa and Machuki (2012), found that a significant positive association exists among; Return on Assets and age of the members of the board, women on the board, educational qualifications and members of the board professional specialization; dividends yield (DY) and age of board members and educational qualifications. Sanda, Mikailu and Garba, (2005) concluded that separating the CEO from the board chair favours the firm and that Nigerian listed firms should maintain a board size of ten.

Ongore, K'Obonyo, Ogutu and Bosire (2015) established that gender diversity has a positive effect on firm performance. They also point out that number of female directors observed in their study was significantly lower than male directors. Considering board composition in the Kenyan context, the study shows that gender disparity can affect firm performance. Although it is easy to observe the increase in number of women directors, assessment of the influence and involvement of women directors is more difficult due to the inaccessibility of the boardroom processes. Moreover, researchers have mainly been interested in the bottom-line effects of women directors rather than on their role. Whereas some have found a positive association among gender diversity and firm performance (Letting, Aosa \& Machuki, 2012; Carter et al., 2003; and Erhardt, Werbel, Shrader, 2003), some have concluded that the relationship is negligible (Dale-Olsen, Schone, \& Verner, 2010), and some have even concluded that the overall relationship is negative (Adams \& Ferreira, 2009). Letting, Aosa and Machuki (2012), provide evidence that scholars have focused on the influence of the board members' gender and educational qualification on firm performance. Common attributes of board members are age, level of education, gender, and experience. Therefore, from these attributes, Board diversity can directly or indirectly impact firm performance. The board is responsible for policy development and strategic direction making, thus it is an important part of corporate governance mechanism.

\section{Board Composition}

Board composition maybe defined as the extent to which there exists independence between members of a firm's board and it's CEO. Several approaches have been used to capture this perspective. One considers the proportion of executive board members to total board members (Baysinger, Kosnik \& Turk, 1991) while other approaches focus on the proportion of non-executive board members to total board members. Analysis of the determinants of corporate financial performance is essential for all the stakeholders. Generally, there is not much evidence that board composition has any cross-sectional association to firm performance. Empirical evidence concludes that board composition has no effect on firm performance, and 
absence of an association among leadership structure and firm performance. Shareholder activism ensures there is accountability and transparency in the board dealings.

\section{Firm Performance}

Firm performance is an imperative idea that describes the means and ways through which organizational resources are employed to achieve corporate strategy. It keeps the organization a float and brings about better vision for future opportunities (Hoskisson et al., 1994). Performance of the firm relates to its efficiency, effectiveness, financial viability and relevance. Effectiveness brings out the peculiar abilities which organizations must embrace in ensuring attainment of their missions. Efficiency is described as the unit cost of output which is much less than the input leaving no alternative option through which the input can be reduced for the same amount of output (Machuki \& Aosa, 2011). Financial viability on the other hand has been defined as a firm's ability to harness its financial resources which are its inflow of financial resources that must be greater than the outflow. Relevance is the ability of a firm to develop in ways that consolidate their strengths. Ricardo et al. (2001) defines performance as the ability of a firm to maximize strengths to overcome its weaknesses to neutralize its threats and take advantages of opportunities.

Performance measurement is characterized by measurement difficulties. While the study has zeroed in on performance, some scholars have expressed concern that the field has yielded inconclusive results, often drawing "seemingly conflicting findings" regarding the determinants of performance. Awino (2011) concludes that no single variable can effectively influence a firm's performance. Performance measures are many and varied with some schools of thought advocating for financial performance measures and others for the non-financial performance measures. Not a single measure of performance can completely explain all aspects of the term due to organizational objectives and contextual factors (Snow \& Hambrick, 1980). This may be partly because definition of performance incorporates efficiency-related measures, relating to the input/output models and effectiveness related measures, dealing with issues such as growth, employee satisfaction, commitment, and turnover (Mayer \& Schoorman, 1992; Machuki \& Aosa, 2011). Sometimes, performance is conceptually confused with productivity. Productivity is defined as a ratio which depicts the volume of work completed within a defined period of time. Performance is therefore broader, and productivity is one of its indicators (Ricardo, 2001).

Firm performance usually represents the quality of the firm's ongoing relationship with the environment. It can be represented by growth, profitability, and other non-financial indicators. Firm performance depends 
on the context and incorporates indicators in multiple analysis levels (Kaplan \& Norton, 1992). While its description refers to a particular point in time, development, periodic change and varied time scales will need to be considered. Static efficiency may lead to instability in the long run and a temporary misfit could be required to attain long-term dynamic fit. Due to this, incompatible short-term and long-term alliances need to be sorted out in firm performance. It also needs to show how a firm is effectively exploiting available resources while generating new ones.

Firm performance may also be said to be a multi-dimensional construct (Chakravathy, 1986); which a single index may not necessarily be able to give a detailed understanding of relationship compared to the particular construct of interest. Different performance measures exist including both long-term and short-term market performance measures. Studies document several measures that have been used to varying extent including market value added (MVA), return on assets (ROA), economic value added (EVA), free cash flow enhancement, earnings per share (EPS) enhancement, asset enhancement, dividend enhancement, and revenue enhancement (Abdullah, 2004). For instance, Dehaene et al. (2001) adopted return on equity (ROE) and return on assets (ROA) as measures of firms' performance and concluded that this was effective in providing adequate performance information while Chen et al. (2005) suggested that market related measures were better and thus used the market-to-book ratio in their study of firms. Hong Kong. Judge et al. (2003) used several indicators which included both quantitative and qualitative measures such as profitability, customer satisfaction, product/service quality, capacity optimisation and business process enhancement in assessment of institutional performance. Firm performance remains a challenging concept both in terms of how it should be defined and measured because of its multifaceted and multidimensional nature. Most studies of firm performance posit that performance is a dependent variable and seek to identify variables that explain variation in terms of performance.

Ocasio, 1994 and Hoskisson et al., 1994 find that accounting-based financial measures, market-based measures including combinations of both have been relied upon in most studies which focus on the association among corporate governance and profitability of an institution. Accounting based performance indicators of the firm rely on accounting ratios that do not incorporate the stock market variables while measures that are based on market variables include the Tobins $Q$ and return on the market which incorporate the stock price. Financial accounting measures despite having been criticized many times have been relied on by many studies. The criticism emanates from the fact that such measures (1) can aid in creative accounting through, manipulating accounting information; (2) may likely 
devalue assets; (3) generate biases as a result of accounting policies and methods adopted by the firm; and (4) lack standardization in financial reporting as some jurisdictions have not adopted international financial reporting standards. Also, interpretation of financial accounting statements and ratios is subjective in case of cross cutting industry participation by the various firms (Nayyar, 1992) or where the firm's ownership structures are varied.

In contrast, market-based measures have several benefits. Risk adjusted performance measurement is reflected in these indicators; they are not negatively impacted upon by cross cutting industry or multinational contexts (Nayyar, 1992). Deckop, 1987 concludes that the main reason for this is that market-based performance indicators are in control of external forces and not within the management's control. Literature does not document any consensus concerning the efficacy of dependence on either accounting-based indicators or market-based indicators, many studies have resorted to using a mix of the financial performance measures.

\section{Methodology}

\section{Research Design, Data and Sampling}

Using data from a developing country, Kenya, a descriptive correlational research design was adopted. The data required was collected for a ten-year period from 2006 to 2015 for the institutions that were sampled from the financial sector in Kenya, through data collection sheets from annual reports and company websites. The population of the research was 3989 financial institutions in Kenya comprising of five regulators, 43 commercial banks, 10 Investment banks, two development banks and one mortgage finance company, 41 insurance companies, nine deposit taking micro-finance institutions, and 3,887 Sacco's (http://www.centralbank.go.ke). The study followed the simple stratified random sampling in obtaining viable set of data sets and sampled 98 firms from all the categories.

\section{Data Analysis}

Multiple regression analysis was used in analysis of the collected data. Parametric and non-parametric methodologies were used. Nonparametric (or non-distribution) inferential statistical methods are mathematical procedures to test statistical hypothesis which, unlike parametric statistics, do not make any assumptions about the probability distributions of the assessed variables. Tests of goodness of fit including the adjusted coefficient of determination $\left(\bar{R}^{2}\right)$, t-tests, standard error of estimate (Se) and ANOVA were also done. The regression was performed in the form of a panel; several panel regression options, fixed effects, random effects, 
OLS, generalized squares (GLS), and panel that is dynamic were performed. Because OLS makes no use of the information contained in the unequal variability exhibited by the predictor and to ensure that the analysis produces the best linear estimators GLS has also been used. The General Estimation Equation (GEE) procedure has been used to extend the generalized linear model (GLM) to allow for repeat measurements. This allowed analysis of the variables of the study over the ten-year period in the research.

\section{Results}

The procedure for Generalized Estimating Equations (GEE) was applied in extending the Generalized Linear Model (GLM) to enable the researcher to analyze repeated data measurements. The GLM repeated data measures technique affords examination of variance in cases where similar measurements are done several times on each subject or case. For instance, ROA was measured for 10 years in this study. By adopting the general linear model technique, the study tested the hypotheses regarding influence of both the between-subjects elements and the within-subjects elements. These explored relationships among elements in addition to influence of individual elements. Furthermore, the influence of constant covariates and covariate interactions with the between-subjects elements were included. The GLM repeated measures technique enabled the researcher to determine the values of multiple dependent scale variables obtained at multiple time periods, based on their association to categorical and scale independent variables and the time periods at which they were obtained. This section presents the result of how ROA depend on gender diversity of boards and board composition using the GEE procedure. The model information table 1 below summarizes the section on modelling selection to ensure that the procedure fits the appropriate model.

Table 1: Model Information

\begin{tabular}{|c|c|c|}
\hline \multicolumn{2}{|c|}{ Dependent Variable } & Return on Assets \\
\hline \multicolumn{2}{|c|}{ Probability Distribution } & Normal \\
\hline \multicolumn{2}{|c|}{ Link Function } & Identity \\
\hline Subject Effect & 1 & Name \\
\hline Within-Subject Effect & 1 & Year \\
\hline \multicolumn{2}{|c|}{ Working Correlation Matrix Structure } & Unstructured \\
\hline
\end{tabular}

Author, 2017

The Normal Probability Distribution (NPD) is appropriate since return on total asset is a scale variable and its values take a symmetric, bell-shaped distribution about a central (mean) value. The link function is an alteration of the dependent variable that permits prediction of the model. The following link function which can also be used with any distribution is used - Identity, $\mathrm{f}(\mathrm{x})=\mathrm{x}$. The dependent variable is not altered. 
The name captures the names of the firms in this study, which are the main subjects of the study. The year captures the within subject data. The working correlation matrix is a representative of the within-subject dependencies. The size is indicated by the number of observations and thus the amalgamation of values of within-subject variables. There are five possible structures: Independent which assumes that repeated observations are uncorrelated; AR (1) in which it is assumed that repeated observations have a first-order autoregressive association and that the correlation among any two elements is equal to $r$ for adjacent elements, $r^{2}$ for elements that are separated by a third, and so on. $r$ is constrained so that $-1<r<1$; Exchangeable which assumed that the structure has homogenous correlations between elements, it is also known as a compound symmetry structure; M-dependent in which it is assumed that consecutive observations have a common correlation coefficient, pairs of observations separated by a third have a common correlation coefficient, and so on, through pairs of observations separated by $\mathrm{m}-1$ other observations. Observations with greater separation are assumed to be uncorrelated; unstructured, which is a completely general correlation matrix (help ibm.spss.statistics, 2017). The Working Correlation Matrix Structure with the best result, based on the data in this study is unstructured. The other structure does not tell much. The results are presented in sections 4.1 and 4.2 , in summary the results indicate that gender diversity of boards and board composition operationalized through the number of female board members and proportion on non-executive directors does not significantly affects firm performance.

\section{Gender Diversity of Boards and Firm Performance}

The GEE results for firm performance and board diversity operationalized through ROA and the categories of number of female directors on the board respectively are presented in tables 2 .

Table 2a: Categorical Variable Information

\begin{tabular}{|c|c|c|c|c|}
\hline & & & $\mathrm{N}$ & Percent \\
\hline \multirow{4}{*}{ Factor } & \multirow{4}{*}{$\begin{array}{c}\text { Categories Of Number of } \\
\text { female directors on the } \\
\text { board }\end{array}$} & No Female Director in The Board & 100 & $12.7 \%$ \\
\hline & & 1 to 2 Female Directors In The Board & 412 & $52.2 \%$ \\
\hline & & $\begin{array}{c}3 \text { and More Female directors in The } \\
\text { Board }\end{array}$ & 278 & $35.2 \%$ \\
\hline & & Total & 790 & $100.0 \%$ \\
\hline
\end{tabular}


Table 2b: Goodness of Fit ${ }^{\mathrm{a}}$

\begin{tabular}{|c|c|}
\hline & Value \\
\hline Quasi Likelihood under Independence Model Criterion (QIC) & 17882.429 \\
\hline $\begin{array}{l}\text { Corrected Quasi Likelihood under Independence Model } \\
\text { Criterion (QICC) }\end{array}$ & 17624.540 \\
\hline
\end{tabular}

Table 2c: Tests of Model Effects

\begin{tabular}{|c|c|c|c|}
\hline \multirow{2}{*}{ Source } & \multicolumn{3}{|c|}{ Type III } \\
\cline { 2 - 4 } & $\begin{array}{c}\text { Wald Chi- } \\
\text { Square }\end{array}$ & df & Sig. \\
\hline $\begin{array}{c}\text { (Interce } \\
\text { pt) }\end{array}$ & 1.392 & 1 & .238 \\
$\begin{array}{c}\text { NFmDB } \\
\text { Cla }\end{array}$ & 3.488 & 2 & .175 \\
\hline
\end{tabular}

Table 2d: Parameter Estimates

\begin{tabular}{|c|c|c|c|c|c|c|c|}
\hline & \multirow[t]{2}{*}{ B } & \multirow[t]{2}{*}{$\begin{array}{l}\text { Std. } \\
\text { Error }\end{array}$} & \multicolumn{2}{|c|}{$\begin{array}{l}\text { 95\% Wald Confidence } \\
\text { Interval } \\
\end{array}$} & \multicolumn{3}{|c|}{ Hypothesis Test } \\
\hline & & & Lower & Upper & $\begin{array}{l}\text { Wald Chi- } \\
\text { Square }\end{array}$ & df & Sig. \\
\hline (Intercept) & 3.703 & .7689 & 2.196 & 5.209 & 23.190 & 1 & .000 \\
\hline $\begin{array}{c}{[\mathrm{NFmDBCl}} \\
\mathrm{a}=0]\end{array}$ & -6.645 & 4.2404 & -14.956 & 1.667 & 2.455 & 1 & .117 \\
\hline $\begin{array}{c}{[\mathrm{NFmDBCl}} \\
\mathrm{a}=1]\end{array}$ & .702 & .8074 & -.880 & 2.284 & .756 & 1 & .385 \\
\hline $\begin{array}{c}\text { [NFmDBCl } \\
a=2] \\
\text { (Scale) }\end{array}$ & $\begin{array}{c}0^{\mathrm{a}} \\
22.387\end{array}$ & & . & . & & . & . \\
\hline
\end{tabular}

a. Set to zero because this parameter is redundant.

Table 2 e: Estimated Marginal Means

\begin{tabular}{|c|c|c|c|c|}
\hline $\begin{array}{c}\text { Categories Of Number of female } \\
\text { directors on the board }\end{array}$ & Mean & Std. Error & \multicolumn{2}{|c|}{$\begin{array}{c}95 \% \text { Wald Confidence } \\
\text { Interval }\end{array}$} \\
\cline { 4 - 5 } & & Lower & Upper \\
\hline $\begin{array}{c}\text { No Female Director in The } \\
\text { Board }\end{array}$ & -2.942 & 4.170 & -11.115 & 5.231 \\
1 to 2 Female Directors In The \\
$\begin{array}{c}\text { Board } \\
3 \text { and More Female directors in } \\
\text { The Board }\end{array}$ & 4.404 & .788 & 2.859 & 5.949 \\
\hline
\end{tabular}


Table 2 f: Working Correlation Matrix ${ }^{\mathrm{a}}$

\begin{tabular}{|c|c|c|c|c|c|c|c|c|c|c|}
\hline \multirow[b]{2}{*}{$\begin{array}{c}\text { Measureme } \\
\text { nt }\end{array}$} & \multicolumn{10}{|c|}{ Measurement } \\
\hline & $\begin{array}{c}{[\text { Yea }} \\
\mathrm{r}= \\
200 \\
6]\end{array}$ & $\begin{array}{c}{[\text { Yea }} \\
r= \\
2007 \\
]\end{array}$ & $\begin{array}{c}{[\text { Yea }} \\
\mathrm{r}= \\
2008 \\
]\end{array}$ & $\begin{array}{c}{[\text { Yea }} \\
r= \\
2009 \\
]\end{array}$ & $\begin{array}{c}{[\text { Yea }} \\
\mathrm{r}= \\
201 \\
0]\end{array}$ & $\begin{array}{c}{[Y e a} \\
\mathrm{r}= \\
2011 \\
]\end{array}$ & $\begin{array}{c}\text { [Yea } \\
\mathrm{r}= \\
2012 \\
]\end{array}$ & $\begin{array}{c}{[\text { Yea }} \\
\mathrm{r}= \\
2013 \\
]\end{array}$ & $\begin{array}{c}\text { [Yea } \\
\mathrm{r}= \\
2014 \\
\text { ] }\end{array}$ & $\begin{array}{c}{[\text { Yea }} \\
\text { r } \\
201 \\
5]\end{array}$ \\
\hline $\begin{array}{c}{[\text { Year = }} \\
\text { 2006] }\end{array}$ & 1.00 & .915 & .915 & .698 & .616 & .427 & .501 & .472 & .440 & .372 \\
\hline $\begin{array}{c}\text { [Year = } \\
\text { 2007] }\end{array}$ & .915 & 1.00 & .915 & .791 & .740 & .575 & .632 & .638 & .577 & .469 \\
\hline $\begin{array}{c}{[\text { Year }=} \\
2008]\end{array}$ & .915 & .915 & 1.00 & .863 & .724 & .613 & .650 & .700 & .559 & .504 \\
\hline $\begin{array}{c}\text { [Year }= \\
\text { 2009] }\end{array}$ & .698 & .791 & .863 & 1.00 & .635 & .487 & .603 & .659 & .511 & .450 \\
\hline $\begin{array}{c}\text { [Year = } \\
\text { 2010] }\end{array}$ & .616 & .740 & .724 & .635 & 1.00 & .586 & .697 & .681 & .524 & .464 \\
\hline $\begin{array}{c}\text { [Year = } \\
\text { 2011] }\end{array}$ & .427 & .575 & .613 & .487 & .586 & 1.00 & .678 & .616 & .489 & .425 \\
\hline $\begin{array}{c}\text { [Year }= \\
2012]\end{array}$ & .501 & .632 & .650 & .603 & .697 & .678 & 1.00 & .779 & .606 & .562 \\
\hline $\begin{array}{c}\text { [Year }= \\
\text { 2013] }\end{array}$ & .472 & .638 & .700 & .659 & .681 & .616 & .779 & 1.00 & .696 & .722 \\
\hline $\begin{array}{c}\text { [Year = } \\
\text { 2014] }\end{array}$ & .440 & .577 & .559 & .511 & .524 & .489 & .606 & .696 & 1.00 & .530 \\
\hline $\begin{array}{c}{[\text { Year }=} \\
2015] \\
\end{array}$ & .372 & .469 & .504 & .450 & .464 & .425 & .562 & .722 & .530 & 1.00 \\
\hline
\end{tabular}

a. Ridge value was added to the working correlation matrix to make it positive definite.

Table $2 \mathrm{~g}$ : General Estimable Function

\begin{tabular}{|c|c|c|c|}
\hline \multirow{2}{*}{ Parameter } & \multicolumn{3}{|c|}{ Contrast } \\
\cline { 2 - 4 } & L1 & L2 & L3 \\
\hline (Intercept) & 1 & 0 & 0 \\
{$\left[\begin{array}{c}\text { NFmDBCl } \\
a=0]\end{array}\right.$} & 0 & 1 & 0 \\
{$\left[\begin{array}{c}\text { NFmDBCl } \\
a=1]\end{array}\right.$} & 0 & 0 & 1 \\
{$\left[\begin{array}{c}\text { NFmDBCl } \\
a=2]\end{array}\right.$} & 1 & -1 & -1 \\
\hline
\end{tabular}

Table 2a provides the results for the three categories of board diversity that were identified being no female director on the board $(12.7 \%$ of the firms), 1 to 2 female directors (52.2\% of the firms) and the third category 3 or more female directors (35.2\% of the firms). Table $2 \mathrm{~b}$ shows that the unstructured correlation structure provides a better model and is used in this section. Table 5.10d provides the reference category for presence of 3 or more female directors is $\mathrm{NFmDBCla}=2$, that is, firms with 3 or more female directors; and the value of 0.702 for $\mathrm{NFmDBCla}=1$ means that, all 
other things being equal, we would expect the ROA of firms with 1 to 2 directors to be 0.702 higher than firms with 3 or more female directors with a significance of 0.385 ; and ROA for no female director on the board to be 6.645 lower than that of 1 to 2 female directors with a significance of 0.117 indicating that this association is not statistically significant. Overall the findings show that female directors impact firm performance, table 2e reveals that the mean ROA is $-2.94 \%$ for firms with no female director on the board, $4.4 \%$ for firms with 1 to 2 female directors on the board and $3.7 \%$ for firms with 3 or more female directors, however this relationship is not statistically significant. This means that diversity of the board is not a potential predictor of firm performance as measured by ROA. Table $2 \mathrm{f}$ indicate that there is no information in the history as years 2006 and 2015 have very low correlation, the correlation decreases as the gap in the years increase.

\section{Board Composition and Firm Performance}

The GEE results for firm performance and board composition operationalized through ROA and the categories of number of independent directors are presented in table 3.

Table 3a: Categorical Variable Information

\begin{tabular}{|ccc|c|c|}
\hline \multirow{3}{*}{ Factor } & & $\mathrm{N}$ & Percent \\
\hline & $\begin{array}{c}\text { Categories of Number } \\
\text { of independent }\end{array}$ & Absence of Independent Director & 320 & $40.5 \%$ \\
& directors on the board & Presence of Independent Director & 470 & $59.5 \%$ \\
& Total & 790 & $100.0 \%$ \\
\hline
\end{tabular}

Table 3b: Goodness of Fit ${ }^{\mathrm{a}}$

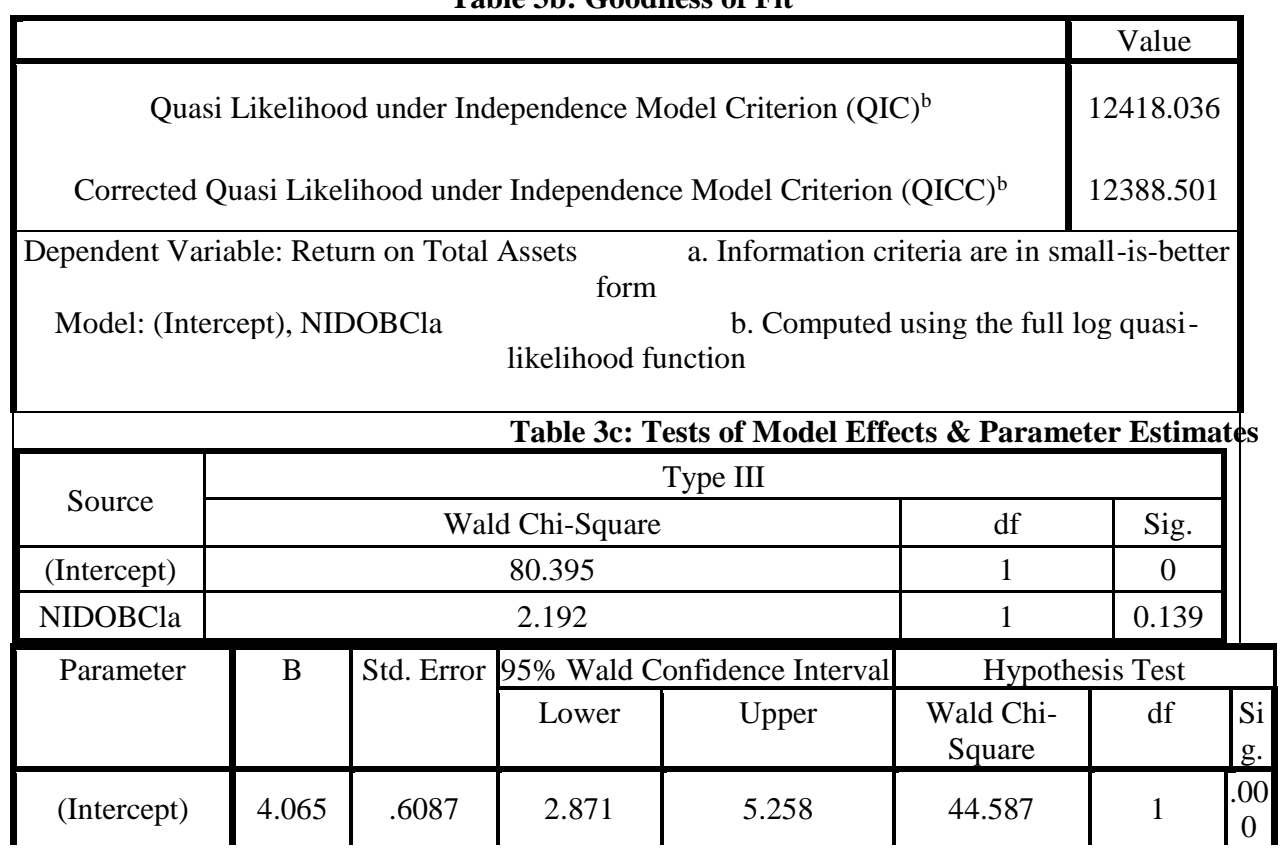




\begin{tabular}{|c|c|c|c|c|c|c|c|}
{$[$ NIDOBCla $=0]$} & -1.152 & .7781 & -2.677 & .373 & 2.192 & 1 & .13 \\
$\begin{array}{c}\text { [NIDOBCla }=1] \\
(\text { Scale })\end{array}$ & $0^{\mathrm{a}}$ &. &. &. &. &. &. \\
\hline
\end{tabular}

Table 3d: Estimated Marginal Means

\begin{tabular}{|c|c|c|c|c|}
\hline $\begin{array}{c}\text { Categories of Number of } \\
\text { independent directors on the } \\
\text { board }\end{array}$ & Mean & Std. Error & \multicolumn{2}{|c|}{$95 \%$ Wald Confidence Interval } \\
\hline Absence of Independent \\
$\begin{array}{c}\text { Directors } \\
\text { Presence of Independent } \\
\text { Directors }\end{array}$ & 2.912502 & \multicolumn{2}{|c|}{ Lower } & Upper \\
\hline $\begin{array}{c}48474 \\
60870 \\
86\end{array}$ & 4.064545 & 2.871498 & 3.862583 \\
\hline
\end{tabular}

Table 3e: Working Correlation Matrix ${ }^{a}$

\begin{tabular}{|c|c|c|c|c|c|c|c|c|c|c|}
\hline \multirow[b]{2}{*}{ Measurement } & \multicolumn{10}{|c|}{ Measurement[Year] } \\
\hline & $\begin{array}{c}2006 \\
]\end{array}$ & 2007] & $\begin{array}{c}2008 \\
]\end{array}$ & 2009] & $\begin{array}{c}201 \\
0]\end{array}$ & $\begin{array}{c}2011 \\
]\end{array}$ & $\begin{array}{c}2012 \\
]\end{array}$ & 2013] & $\begin{array}{c}201 \\
4]\end{array}$ & $\begin{array}{c}201 \\
5]\end{array}$ \\
\hline$[$ Year $=2006$ & 1.00 & .948 & .948 & .679 & $\begin{array}{c}.57 \\
6\end{array}$ & .267 & .349 & .320 & .310 & $\begin{array}{c}.26 \\
2\end{array}$ \\
\hline$[$ Year $=2007]$ & .948 & 1.00 & .948 & .733 & $\begin{array}{c}.67 \\
6\end{array}$ & .402 & .458 & .479 & .429 & $\begin{array}{c}.31 \\
9\end{array}$ \\
\hline$[$ Year $=2008]$ & .948 & .948 & 1.00 & .766 & $\begin{array}{c}.58 \\
0\end{array}$ & .385 & .414 & .498 & .331 & $\begin{array}{c}.29 \\
8\end{array}$ \\
\hline$[$ Year $=2009]$ & .679 & .733 & .766 & 1.00 & $\begin{array}{c}.54 \\
6\end{array}$ & .297 & .439 & .534 & .355 & $\begin{array}{c}.31 \\
3\end{array}$ \\
\hline$[$ Year $=2010]$ & .576 & .676 & .580 & .546 & $\begin{array}{c}1.0 \\
0\end{array}$ & .458 & .593 & .582 & .391 & $\begin{array}{c}.35 \\
1\end{array}$ \\
\hline$[$ Year $=2011]$ & .267 & .402 & .385 & .297 & $\begin{array}{c}.45 \\
8\end{array}$ & 1.00 & .532 & .453 & .306 & $\begin{array}{c}.26 \\
1\end{array}$ \\
\hline$[$ Year $=2012]$ & .349 & .458 & .414 & .439 & $\begin{array}{c}.59 \\
3\end{array}$ & .532 & 1.00 & .665 & .451 & $\begin{array}{c}.43 \\
4\end{array}$ \\
\hline$[$ Year $=2013]$ & .320 & .479 & .498 & .534 & $\begin{array}{l}.58 \\
2\end{array}$ & .453 & .665 & 1.00 & .594 & $\begin{array}{c}.67 \\
9\end{array}$ \\
\hline$[$ Year $=2014]$ & .310 & .429 & .331 & .355 & $\begin{array}{c}.39 \\
1\end{array}$ & .306 & .451 & .594 & 1.00 & $\begin{array}{c}.43 \\
8\end{array}$ \\
\hline$[$ Year $=2015]$ & .262 & .319 & .298 & .313 & $\begin{array}{c}.35 \\
1 \\
\end{array}$ & .261 & .434 & .679 & .438 & $\begin{array}{c}1.0 \\
0\end{array}$ \\
\hline
\end{tabular}

Dependent Variable: Return on Total Assets

Model: (Intercept), NIDOBCla

a. Ridge value was added to the working correlation matrix to make it positive definite.

Table 3f: General Estimable Function

\begin{tabular}{|c|c|c|}
\hline \multirow{2}{*}{ Parameter } & \multicolumn{2}{|c|}{ Contrast } \\
\cline { 2 - 3 } & L1 & L2 \\
\hline (Intercept $)$ & 1 & 0 \\
\hline$[$ NIDOBCla $=0]$ & 0 & -1 \\
\hline$[$ NIDOBCla $=1]$ & 1 & -1 \\
\hline
\end{tabular}

Dependent Variable: Return on Total Assets Model: (Intercept), NIDOBCla 
Table 3a provides the results for the two categories of board composition being presence of independent directors and absence where $40.5 \%$ of the firms had no independent director while $59.5 \%$ had independent directors. Table $3 \mathrm{~b}$ shows that the unstructured correlation structure provides a better model and is used in this section. Table $3 \mathrm{c}$ provides the reference category for presence of independent directors is NIDOBCla $=1$, that is, firms with independent directors; and the value of 1.152 for NIDOBCla $=0$ means that, all other things being equal, the ROA of firms without independent directors should be -1.152 lower than firms with independent directors with a significance of 0.139 , showing that this relationship is not statistically significant. In overall terms, these results indicate that the presence of independent directors improves performance. Table $3 \mathrm{~d}$ shows that the mean ROA is $4.06 \%$ for firms with independent directors and $2.91 \%$ for firms without independent directors. However, this relationship is not statistically significant. This means that board composition is not a potential predictor of performance as measured by ROA. Table 3e indicates that there is no information in the history as years 2006 and 2015 have very low correlation, the correlation decreases as the gap in the years increase.

\section{Conclusion \& Recommendations}

The results presented mixed findings on the association among gender diversity of boards, board compositions and performance of financial institutions in Kenya. While several studies document a positive influence of board structure variables on performance, others found the opposite. The findings in this study conclude that both gender diversity of boards and board composition do not affect performance of financial institutions in Kenya. The mixed findings could be linked to the variety of methodologies and definitions of variables used and the study contextual factors that were not included in the analysis by the models used.

Prior studies have postulated that corporate governance is critical to organizational success. Board structures have also been linked to performance. However, limited empirical literature existed on the influence of gender diversity of boards and board composition on firm performance in emerging economies. This study sought to establish this relationship. The study results will arouse deeper academic discourse of the relationship of these concepts; form a basis for strengthening policy as well as managerial practice in financial institutions in Kenya and beyond. 


\section{References:}

1. Abdullah, S. (2004). Board Composition, CEO Duality and Performance among Malaysian Listed Companies. Corporate Governance, 4 (4), 47-61.

2. Adams, R., \& Ferreira, D. (2009). Women in the boardroom and their impact on governance and performance. Journal of Financial Economics, 94(2): 291-309.

3. Awino, Z.B. (2011). Strategic management: An empirical investigation of selected strategy variables on Firm' performance: A study of supply chain management in large private manufacturing firms in Kenya. Prime Journals, 1(1), 9-18.

4. Baysinger, B. D., Kosnik, R.D. \& Turk, T.A. (1991). Effects of board and ownership structure on corporate R\&D strategy. Academy of Management Journal, 34, 205-214.

5. Becker, G. S. (1964). Human Capital: A Theoretical and Empirical Analysis, With Special Reference to Education. New York: National Bureau of Economic Research.

6. Carter, D.A., D’Souza, F., Simkins, B. \& Simpson, W. (2010), 'The Gender and Ethnic Diversity of US Boards and Board Committees and Firm Financial Performance', Corporate Governance: An International Review, 18(5): 396-414.

7. Carter, D.A., Simkins, B.J., Simpson, W.G. (2003). Corporate governance, board diversity and firm value. Financial Review, 38, $33-53$.

8. Chakravathy, B.S. (1986). Measuring Strategic Performance. Strategic Management Journal, 7(5): 437-458.

9. Chen, Z., Cheung, Y., Stouraitis, A. \& Wong, A. W. S. (2005). Ownership Concentration, Firm Performance, and Dividend Policy in Hong Kong. Pacific-Basin Finance Journal, 13(4), 431-449.

10. Dale-Olsen, H., Schøne, P., \& Verner, M. (2013).Diversity among Norwegian Boards of Directors: Does a Quota for Women Improve Firm Performance?. Feminist Economics, 19(4), 110-135.

11. Dalton, D. R.; Daily, C. M.; Ellstrand, E.A. \& Johnson, J. L. (1998). Meta-Analytic Review of Board Composition, Leadership Structure and Financial Performance. Strategic Management Journal, 19 (3), 269-290.

12. De Andres, P., Azofra, V., \& Lopez, F. (2005). Corporate boards in OECD countries: Size, composition, functioning and effectiveness. Corporate Governance: An International Review, 13(2), 197-210. doi:10.1111/j.1467-8683.2005.00418.x

13. Deckop, J. (1987). Top executive compensation and the pay-forperformance issue. In D. B. Balkin and L. R. Gomez-Mejia (eds.), 
New Perspectives in Compensation. Prentice Hall, Englewood Cliffs, NJ, 285-293.

14. Dehaene, A, De Vuyst, V \& Ooghe, H 2001, 'Corporate Performance and Board Structure in Belgian Companies', Long Range Planning, vol. 34, no. 3, pp. 383-98.

15. Dejardin, Amelita King (2009) Gender (In) equality, Globalization and Governance, Working Paper No. 92. Policy Integration and Statistics Department, Geneva: International Labour Organization.

16. Dezsö, C. L., \& Ross, D. G. (2012). Does Female Representation in Top Management Improve Firm Performance? A Panel Data Investigation. Strategic Management Journal, 33(9), 1072-1089. http://doi.org/10.1002/smj.1955

17. Dutta, P., \& Bose, S. (2006). Gender Diversity in the Boardroom and Financial Performance of Commercial Banks: Evidence from Bangladesh. The Cost and Management. 34(6), 70-74.

18. Erhardt, N., Werbel, J., \& Shrader, C. (2003). Board of Director Diversity and Firm Financial Performance. Blackwell Publishing Ltd, 102-111.

19. Evan, W. M., \& Freeman, R. E. (1988). A stakeholder theory of the modern corporation: Kant- ian capitalism. In T. Beauchamp \& N. Bowie (Eds.), Ethical theory and business: 75-93. Englewood Cliffs, NJ: Prentice Hall.

20. Farrell, K.A. \& Hersch, P.L. (2001), “Additions to corporate boards: Does gender matter?", SSRN, November 28, 1-30.

21. Herring Cedric (2009). "Does Diversity Pay? Race, Gender, and the Business Case for Diversity." American Sociological Review 74(2):208-224.

22. Hillman, A., \& Dalziel, T. (2003). Boards of Directors and Firm Performance: Integrating Agency and Resource Dependence Perspectives. The Academy of Management Review 28(3), 383-396.

23. Hoskisson, R. E., Johnson, R. A. \& Moesel, D.D. (1994). Corporate divestiture intensity in restructuring firms: Effects of governance, strategy, and performance. Academy of Management Journal, 37, $1207-1251$.

24. Jackling, B. \& Johl, S. (2009). Board Structure and Firm Performance: Evidence from India's Top Companies. Corporate Governance: An International Review 17(4), 492- 509.

25. Judge, W. Q., Naoumova, I. \& Koutzevol, N. (2003), Corporate Governance and Firm Performance in Russia: An Empirical Study. Journal of World Business, 38 (4): 385-396.

26. Kamaara, M. W., Gachunga, H. \& Waititu, A.G. (2013). The relationship between board of director characteristics and 
performance of commercial state corporations in Kenya. International Journal of Innovate Research and Studies, 2, (11), 124136.

27. Kang, H., Cheng, M., \& Gray, S. J. (2007). Corporate Governance and Board Composition: Diversity and Independence of Australian Boards. Corporate Governance: An International Review, 15(2), 194207.

28. Kaplan, R. S, \& Norton, D.P. (1992). The balanced scorecardmeasures that drive performance. Harvard Business Review, Jan-Feb, 719.

29. Kiel, G. C., \& Nicholson, G. J. (2003). Board composition and corporate performance: How the Australian experience informs contrasting theories of corporate governance. Corporate Governance: An International Review, 11(3), 189-205. doi:10.1111/14678683.00318

30. Letting N., Aosa E., \& Machuki, V.N. (2012). Board diversity and performance of companies listed in Nairobi Securities Exchange. International Journal of Humanities and Social Science, 2(11), 172182.

31. Machuki, V.N., \& Aosa, E. (2011). The influence of the external environment on performance of publicly quoted companies in Kenya. Prime Journal of Business Administration and Management, 1(7), 205-218.

32. Marimuthu, M. \& Kolandaisamy I. (2009). Can demographic diversity in top management team contribute for greater financial performance? An empirical discussion. The Journal of International Social Research, 2(8) 273-286.

33. Mayer, R. C., \& Schoorman, F. D. (1992). Differentiating antecedents of organizational commitment: a test of March and Simon's model. Journal of Organizational Behavior, 19, 15-28.

34. Miller D, \& Shamsie J. (1996). The resource-based view of the firm in two environments: The Holly Wood Film Studios from 1936 to 1965. Academy of Management Journal 39: 519 - 543

35. Nayyar, P. R. (1992). Performance effects of three foci in service firms. Academy of Management Journal, 35, 985-1009.

36. Ocasio, W. (1994). Political dynamics and the circulation of power: CEO succession in U.S. industrial corporations, 1960-1990. Administrative Science Quarterly, 39, pp. 285-312.

37. Ongore, V. O., K'Obonyo, P. O., Ogutu, M., \& Bosire, E. M. (2015). Board Composition and Financial Performance: Empirical Analysis of Companies Listed at the Nairobi Securities Exchange. International Journal of Economics and Finance. Issues, 5(4), 23-43. 
38. Pearce, J., \& Zahra, S. (1992). Board composition from a strategic contingency perspective. Journal of Management Studies, 29(4): 411.

39. Pfeffer, J., \& Salancik, G. (1978). The external Control of Organizations: A Resource-Dependence Perspective.

40. Ricardo, R., \& Wade, D. (2001). Corporate performance management: how to build a better organization through measurement driven strategies alignment. Butterworth, Heinemann.

41. Richard A. Johnson and Daniel W. Greening. Special Research Forum on Stakeholders, Social Responsibility, and Performance (Oct., 1999), pp. 564-576

42. Rose, C. (2007). Does female board representation influence firm performance? The Danish evidence. Corporate Governance: An International Review, 15(2), 404-413. doi:10.1111/j.14678683.2007.00570.x

43. Sanda, A., A. Mikailu, \& T. Garba. (2005). Corporate governance mechanisms and firm financial performance in Nigeria. African Economic Research Consortium (pp. 47). Sokoto.

44. Shleifer, A., \& Vishny, R.W. (1997). A survey of corporate governance. Journal of Finance, 52(2), 737-783.

45. Singh, V., Terjesen, S., \& Vinnicombe, S. (2008) Newly appointed directors in the Boardroom: How do women and men differ? European Management Journal, 26(1), 48-58

46. Smith, N., Smith, V. \& Verner, M. (2013): Why Are So Few Females Promoted into CEO and Vice President Positions? Danish Empirical Evidence, 1997-2007, Industrial and Labor Relations Review, 66, 380-408.

47. Snow, C. C. \& Hambrick, D. C. (1980). Measuring organizational strategies: some theoretical and methodological problems. Academy of Management Review, 5, 527-538.

48. Terjesen, S., Sealy, R., \& Singh, V. (2009). Women directors on corporate boards : A review and research agenda. Corporate Governance: An International Review, 17(3): 320-337.

49. Van der Walt, N. T., \& Ingley, C. B. (2003). Board Dynamics and the Influence of Professional Background, Gender and Ethnic Diversity of Directors. Corporate Governance: An International Review, 11(3), 218-234. 